20. Cheberyako, O. (2015). The impact of cooperation with the IMF on financial security in Ukraine // Proceedings of the II International Scientific and Practical Forum "Theory and Practice of Reforming Economic Systems". 226227. [In Ukrainian].

21. Knoema database. URL:https://knoema.com/.(application date: March 1, 2021)
22. State Statistics Service of Ukraine. Official site. URL: http://www.ukrstat.gov.ua/.(application date: March 1, 2021) 23. Agricultural Consulting. Consulting URL:https://farming.org.ua.(application date: March 1, 2021)

Y. Marko, PhD in Economics

Military Strategic Studies Center of Ivan Chernyakhovsky National Defense University of Ukraine, Kyiv, Ukraine

i-tv@ukr.net

ORCID ID 0000-0002-9165-8072,

V. Kuzmenko, Cadet

Taras Shevchenko National University of Kyiv, Kyiv, Ukraine

volodymyr07082000@gmail.com

ORCID ID 0000-0002-1416-0887

\title{
ECONOMETRICS OF NATIONAL SECURITY AND DEFENSE OF UKRAINE
}

The article provides the importance of Ukraine's economic development to ensure national security, highlights the main internal and external threats to Ukraine's national security, such as: hybrid economic war, the "needle" of loans from the International Monetary Fund, communal tariffs, opening the gas market in Ukraine, inefficient introduction of the circulation of domestic agricultural lands and insufficient use of the capabilities of the country's economy. The cyclical nature of economic development is practically proved by distinguishing four phases of economic development of the studied countries for the last ten years, weak efficiency of economic policy of Ukraine and possible applied mechanisms of economic growth. An econometric analysis of GDP of Ukraine and countries that occupy the largest share in Ukrainian imports of goods, the budget of Ukraine and the budget of the Ministry of Defense of Ukraine using the method of least squares and even linear regressions, calculated the intensity of changes in Ukraine's economic processes. The model of gross domestic product of Ukraine depending on the gross domestic product of China, Poland, Russia, Turkey, Germany, Italy, Belarus, the United States and France (nine-factor model), as well as the model of Ukraine's defense budget depending on the domestic gross domestic product product, budget expenditures, taxes, minimum and average wages and inflation (seven-factor model). On the example of the Ministry of Defense of Ukraine as a public sector institution, the registration algorithm for economic (additional) activities by military units and the distribution of revenues to increase the special fund of the state budget of Ukraine and create recovery of the country economy in general.

Keywords: econometrics, elasticity, national security, the paradox of increasing tariff rates, the trade balance, an imported recession.

\section{ТИПОВІ ПОРУШЕННЯ, ЩО ВИЯВЛЯЮТЬСЯ В ПРОЦЕСІ АУДИТУ ВІЙСЬКОВИХ ЧАСТИН ЗБРОЙНИХ СИЛ УКРАЇНИ}

Розглянуто загальні засади внутрішнього аудиту, поняття, суть, а також теоретичні засади та методичні особливості проведення внутрішнього аудиту у військових частинах ЗСУ. Приділено значну увагу меті внутрішнього аудиту в цілому та в ЗСУ зокрема. Дано визначення аудиту та внутрішнього аудиту відповідно до норм чинних нормативно-правових актів України. Детально описано процес планування, організації та безпосереднє проведення внутрішнього аудиту, проведено аналіз нормативно-правової бази щодо проведення внутрішнього аудиту у бюджетних установах $і$, зокрема, у ЗСУ. Особливу увагу приділено етапам аудиту, аналізу типових порушень, що виявляються в процесі внутрішнього аудиту та внутрішнього контролю. Проаналізовано результати внутрішнього аудиту в 20142019 рр., наведено типові порушення, що виявляються в процесі внутрішнього аудиту, та детально розглянуто порушення в 2019 р. Частими причинами порушень стосовно неякісного ведення кількісного обліку військового майна в службах військових частин, які призвели до збитків, ризиків незаконних видатків та нестач, є низький професійний рівень та недбале виконання функціональних обов'язків посадовими особами, призначеними на посади начальників служб,i відповідних посадових осіб військових частин, закріплених на забезпечення, яким за своїми обов'язками належало своєчасно відпрацьовувати документи щодо ведення обліку матеріальних иінностей, витрачання за нормами та списання військового майна, ведення книг обліку втрат та нестач. На сьогодні постає питання впровадження дієвої системи організації внутрішнього аудиту та пристосування його методики до діяльності бюджетних установ, у тому числі, i військових частин ЗСУ в умовах реформування та поглиблення інтеграційних процесів в економіці України.

Ключові слова: фінансовий контроль, внутрішній аудит, аудиторська діяльність, аудитор, фінансова звітність, військова частина, внутрішній фінансовий контроль.

Постановка проблеми. Неналежне виконання функціональних обов'язків з внутрішнього контролю посадовими особами військових частин призводить до неефективного та незаконного використання ресурсів, їхнього псування, не забезпечує збереження військового майна від втрат. Метою внутрішнього аудиту є захист інтересів власників щодо збереження та ефективного використання ресурсів підрозділу, у якому проводиться аудит, а також отримання достовірної та повної інформації для прийняття обґрунтованих управлінських рішень. Основне завдання внутрішнього аудиту - проведення якісного аудиту, розроблення ефективних рекомендацій та подальший контроль їхнього виконання. Аудит не може вважатися завершеним доти, доки не будуть впроваджуватися аудиторські рекомендації та усунені виявлені відхилення. Об'єкти внутрішнього аудиту визначаються його цілями і завданнями. Відповідно до Закону України "Про аудит фінансової звітності та аудиторську діяльність" аудит - це перевірка даних бухгалтерського облікуі показників фрінансової звітності суб'єкта господарювання з метою висловлення незалежної думки аудитора про її достовірність в усіх суттєвих аспектах і відповідність вимогам законів України, положень (стандартів) бухгалтерського обліку або інших правил (внутрішніх положень суб'єктів господарювання) згідно з вимогами користувачів [2]. У ст. 26 Бюджетного кодексу України зазначено, що внутрішнім аудитом є діяльність підрозділу внутрішнього аудиту в бюджетній установі, спрямована на удосконалення системи управління, запобігання фрактам незаконного, неефективного та нерезультативного використання бюджетних коштів, виникненню помилок чи ін- 
ших недоліків у діяльності бюджетної установи та підвідомчих їй бюджетних установ, поліпшення внутрішнього контролю [1]. Особливості проведення аудиторської діяльності ЗСУ регулюються наказом Міністерства оборони України № 475 "Про організацію діяльності з внутрішнього аудиту в системі Міністерства оборони України" [3].

Аналіз останніх досліджень і публікацій. Проблематикою розвитку внутрішнього аудиту займались такі українські вчені, як О. Редько, С. Рудницький, Д. Корінько, В. Немченко, В. Хомутенко, І. Дрозд, А. Богомолов, М. Білуха, Ф. Бутинець, В. Сопко, І. Дмитренко та інші. Щодо зарубіжних вчених, які досліджували проблеми здійснення процесу аудиту, можна назватиЕ. Аренса, Р. Адамса, Дж. Лоббека, Дж. Робертсона, Р. Доджа та ін. Більшість праць українських науковців присвячені дослідженню питань зовнішнього аудиту. Зважаючи на це, питання внутрішнього аудиту і методів його проведення ще недостатньо вивчені та потребують подальших досліджень.

Мета - проаналізувати типові порушення, що виявляються в процесі проведення внутрішнього аудиту у військових частинах 3С України, їхньої суті та значення у фінансово-господарській діяльності військової частини.

Виклад основного матеріалу дослідження. Метою аудиту є надання об'єктивних, обґрунтованих і незалежних рекомендацій, спрямованих на вдосконалення і підвищення ефективності системи управління ризиками підконтрольного суб'єкта. Основними завданнями аудиту є: отримання й оцінка об'єктивних даних про місію (мету)і цілі підконтрольного суб'єкта, ризикові сфери діяльності, процеси та операції, стан організації системи управління ризиками; дослідження, аналіз та оцінки функціонування системи управління ризиками; надання об'єктивних, обґрунтованих і незалежних рекомендацій щодо вдосконалення і підвищення [3].

Процес аудиту складається з таких етапів:

- перший етап - організація аудиту (для аудиту ефективності - попередній аудит);

- другий етап - проведення аудиту;

- третій етап - реалізація результатів аудиту;

- четвертий етап - моніторинг впровадження рекомендацій [3].

Під час підготовки до аудиту визначаються найбільш ризикові напрями діяльності військової установи (частини) з метою їхнього підтвердження чи спростування. Відповідно до вимог Порядку № 145 у військових частинах розробляються та затверджуються Положення про внутрішній контроль, Описи внутрішнього середовища та Адміністративні регламенти. Наказами командирів військових частин призначаються менеджери внутрішнього контролю, створюються робочі групи з оцінки ризиків [4].

За результатами проведення внутрішнього аудиту зазвичай встановлюються гіпотези щодо існування недоліків і створення умов для ризиків в організації ведення обліку військового майна, переплат грошового забезпечення, незаконних видатків унаслідок списання $з$ балансу матеріальних цінностей із порушенням установленого порядку, недотримання правил зберігання військового майна, на які командуванню військової установи (частини) слід звернути увагу, а саме:

- самоусунення керівного складу військових частин від належної організації та забезпечення ефективного фрункціонування системи внутрішнього контролю, неспроможність менеджерів внутрішнього контролю та начальників служб виконувати покладені на них завдання з внутрішнього контролю та управління ризиками відповідно до функціональних обов'язків;

- зниження рівня конфіденційності, достовірності, цілісності відомчої електронної облікової інформації та працездатності інформаційних систем.

На сьогодні цілі внутрішнього аудиту базуються на забезпеченні ефективного внутрішнього контролю витрат, наданні незалежних та об'єктивних рекомендацій з питань фінансово-господарської діяльності. Сутнісні характеристики процедури проведення внутрішнього аудиту, що відображені в цільовій спрямованості, незалежності оцінки, регламентованості, визначають формування та зміст його спеціальних функцій:

- внутрішнього оцінювання (при проведенні оцінки внутрішнього контролю та внутрішніх процедур, дисципліни виконання персоналом вказівок і наданих рекомендацій), експертного дослідження (здійснення експертної оцінки та аналіз ефективності визначених аспектів фінансово-господарської діяльності);

- інформаційного консультування (проведення поточних консультацій інфрормування керівництва про результати перевірок, виявлені факти порушень вимог законодавства або внутрішніх правил) [5].

Проведення внутрішнього аудиту передбачає збирання аудиторських доказів працівниками підрозділу внутрішнього аудиту із застосуванням методів, методичних прийомів і процедур, що забезпечують обґрунтованість висновків за його результатами. Працівники підрозділу внутрішнього аудиту самостійно визначають такі методи, методичні прийоми і процедури, залежно від об'єкта внутрішнього аудиту та відповідно до вимог внутрішніх документів 3 питань проведення внутрішнього аудиту. При цьому, джерелами аудиторських доказів можуть бути:

- дані первинних документів і звітів, у яких зазначається основна інформація про операції, системи та процеси;

- облікові регістри;

- фрінансова, бюджетна, статистична, податкова та інші види звітності;

- $\quad$ звіти про виконання паспортів бюджетних програм;

- інвентаризаційні матеріали (описи, порівняльні відомості);

- розрахунки, декларації, кошториси, калькуляції, договори, контракти, накази, розпорядження;

- матеріали контрольних заходів;

- дані, отримані за результатами експертних перевірок, лабораторних аналізів, контрольних замірів, проведених за участю працівників підрозділу внутрішнього аудиту;

- інші документи та матеріали, необхідні для проведення внутрішнього аудиту [3].

Відповідно до офріційних даних Міністерства оборони України завдяки внутрішнім аудитам впродовж 20142019 рр. економічний ефект від впровадження рекомендацій, наданих за результатами аудитів, перевищує 729 млн грн (табл. 1). 
Результати внутрішніх аудитів у 2014-2019 рр.

\begin{tabular}{|c|c|c|c|c|c|c|}
\hline Показники & 2014 рік & 2015 рік & 2016 рік & 2017 рік & 2018 рік & 2019 рік \\
\hline Вартість відшкодованих втрат та збитків, млн грн & 39,6 & 82,8 & 92,4 & 102,3 & 172,6 & 125,4 \\
\hline $\begin{array}{l}\text { Вартість втрат ресурсів, яким вдалося запобігти під } \\
\text { час проведення аудитів, млн грн }\end{array}$ & 18,6 & 84,2 & 23,0 & 60,1 & 65,4 & 69,9 \\
\hline $\begin{array}{l}\text { Вартість усунення інших фінансових порушень, } \\
\text { які не призвели до втрат та збитків, зменшення } \\
\text { негативного впливу неефективних управлінських } \\
\text { рішень, млн грн }\end{array}$ & 1288,7 & 3489,4 & 4537,6 & 2689,8 & 1892,8 & 4458,9 \\
\hline $\begin{array}{l}\text { Вартість ресурсів, щодо яких усунуто ризики втрат, } \\
\text { збитків і неефективного використання під час } \\
\text { здійснення управління майном і коштами, млн грн }\end{array}$ & - & 266,3 & 2690,3 & 2276,1 & 2152,7 & 1072,5 \\
\hline $\begin{array}{l}\text { Економічний ефект від впровадження рекомендацій, } \\
\text { наданих за результатами аудитів, млн грн }\end{array}$ & 8,6 & 51,0 & 57,1 & 168,2 & 31,3 & 413,4 \\
\hline $\begin{array}{l}\text { Кількість осіб, притягнутих до відповідальності, } \\
\text { всього, у т. ч., } \\
\text { до матеріальної відповідальності, } \\
\text { до дисциплінарної відповідальності }\end{array}$ & $\begin{array}{l}1365 \\
657 \\
708 \\
\end{array}$ & $\begin{array}{l}1397 \\
748 \\
649 \\
\end{array}$ & $\begin{array}{l}1825 \\
904 \\
921 \\
\end{array}$ & $\begin{array}{l}3497 \\
2317 \\
1180 \\
\end{array}$ & $\begin{array}{c}2585 \\
1708 \\
877 \\
\end{array}$ & $\begin{array}{c}2244 \\
1672 \\
572 \\
\end{array}$ \\
\hline $\begin{array}{l}\text { Передано до правоохоронних органів та } \\
\text { поінформовано правоохоронні органи про } \\
\text { результати аудитів: } \\
\text { кількість матеріалів / } \\
\text { сума збитків, млн грн }\end{array}$ & $\begin{array}{l}224 / \\
210,0 \\
\end{array}$ & 223/437,9 & $\begin{array}{l}424 / \\
298,9\end{array}$ & $329 / 425,2$ & $\begin{array}{l}240 / \\
417,3\end{array}$ & $\begin{array}{l}262 / \\
219,8 \\
\end{array}$ \\
\hline
\end{tabular}

Примітка: джерело складено авторами на основі [6].

Щодо 2019 року, то внутрішні аудитори провели:

- операційні аудити (3829 операційних аудитів/попередніх моніторингів або 91 \% усіх проведених аудитів);

- планові та позапланові аудити (7\%);

- інші заходи, які передбачали комісійні перевірки, службові розслідування тощо (рис. 1).

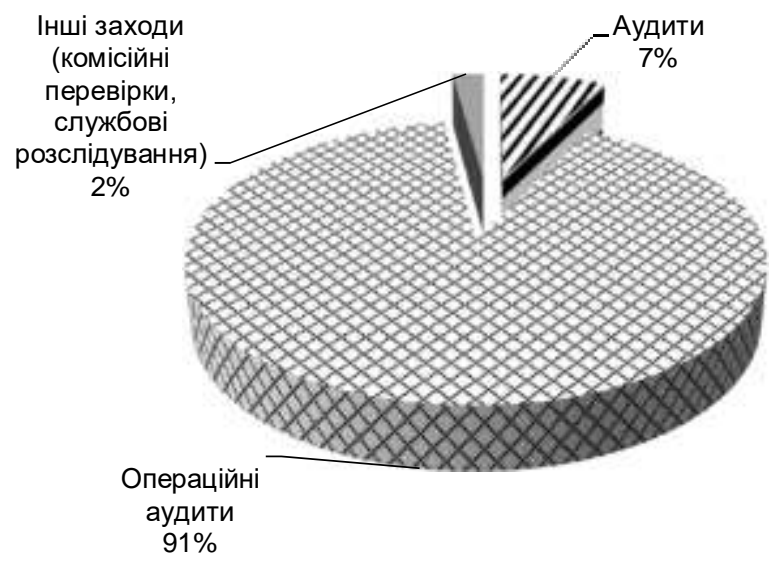

Рис. 1. Структура внутрішніх аудитів у 2019 р.

Джерело складено авторами на основі [6].

У результаті проведених у 2019 р. аудитів:

1) перевірено понад 107,5 млрд грн фінансових і матеріальних ресурсів;

2) встановлено 1361 порушення, що призвело до втрат та збитків на суму майже 266,0 млн грн $(0,25 \%$ охоплених аудитами ресурсів);
3) відшкодовано 125,4 млн грн, що становить 47,1 \% виявлених (із них за матеріалами аудитів, проведених у 2019 р. - 45,8 млн грн або 17,2 \% виявлених);

4) прийнято рішення про відшкодування втрат та збитків на суму 26,4 млн грн;

5) попереджено 69,9 млн грн незаконних втрат та збитків, що на 7 \% більше, ніж у 2018 р. (рис. 2). 


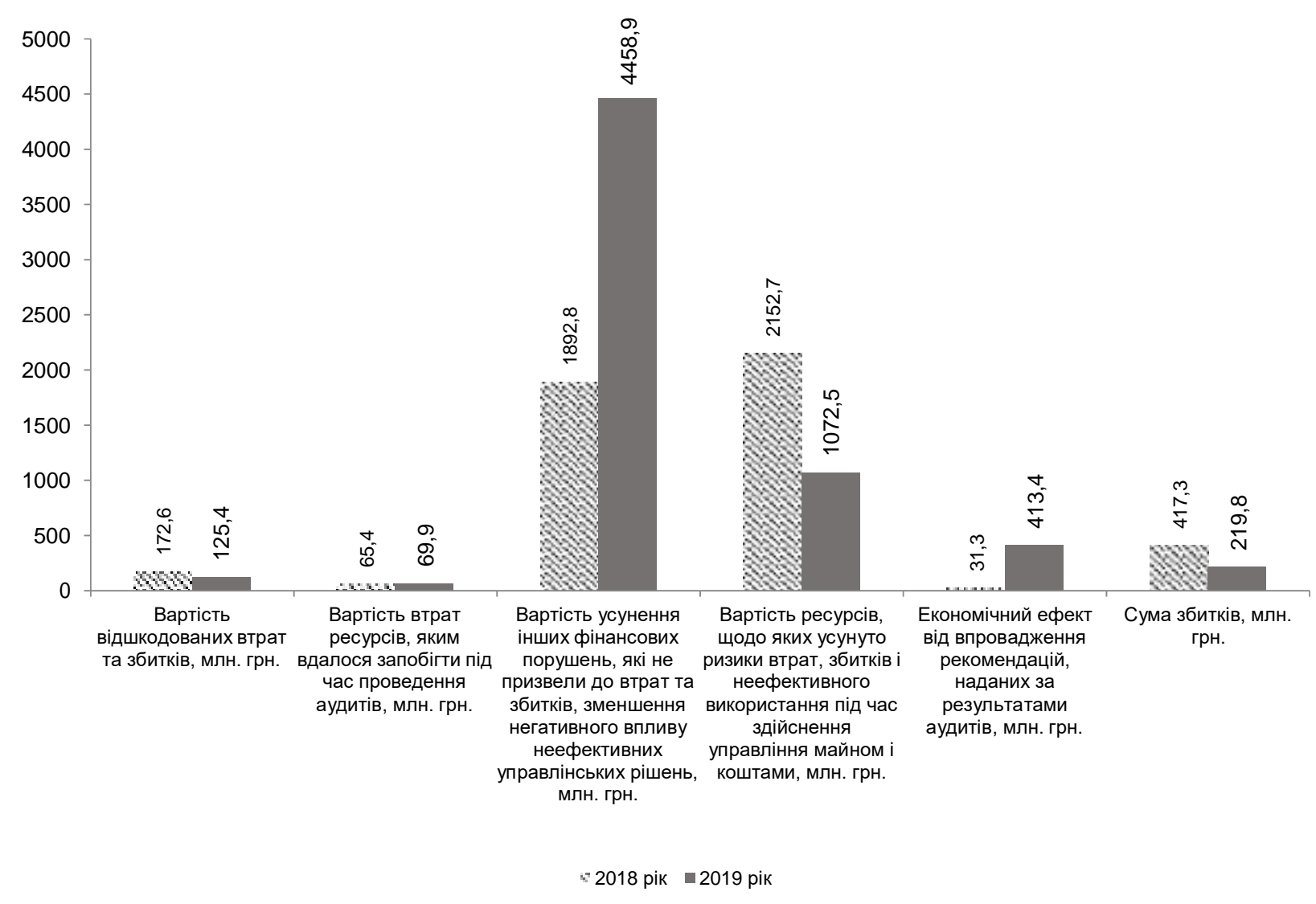

Рис. 2. Результати внутрішніх аудитів у 2018-2019 рр.

Джерело складено авторами на основі [6]

Додатковими ефектами від проведення внутрішніх аудитів були:

- 633 порушення фрінансово-бюджетної дисципліни, що не призвели до втрат на суму 5366,3 млн грн, усунуто 584 таких порушень на суму 4458,9 млн грн або 83,1 \% (із них за матеріалами аудитів, проведених у 2019 р. 4233,7 млн грн або 78,9 \% виявлених);

- ризики в управлінні фрінансами і майном та неефективні управлінські рішення на суму майже 4,0 млрд грн, усунуто на суму майже 1,1 млрд грн (у т. ч., щодо ризиків, усунутих за аудитами 2019 року - 292,6 млн грн);

- 1716 нефінансових порушень, із них 1114 (65\%) усунуто.

До відповідальності притягнуто 2244 особи, у тому числі, до матеріальної - 1672 та до дисциплінарної 572. До правоохоронних органів передано матеріали на суму понад 219,8 млн грн втрат і збитків (у т. ч., матеріали аудитів, проведених наприкінці 2018 р., на суму 24,4 млн грн). За результатами впровадження наданих рекомендацій досягнуто економічний ефект у сумі413,36 млн грн (у т. ч., щодо рекомендацій, наданих у 2019 р. 1,16 млн грн), а також результативність, яка не вимірюється в грошовому вимірнику. Аудиторами встановлено, що через недостовірне ведення номерного обліку та неправильне закріплення військового майна за відповідальними особами призвело до зниження контролю за наявністю майна та виникнення нестач.

Під час проведеного дослідження аудиторських звітів було встановлено, що найбільш поширеними порушеннями щодо виплати грошового забезпечення були:

- порушення правил виплати грошового забезпечення військовослужбовцям, які самовільно залишили частину (СЗЧ), допустили невихід на службу без поважних причин, а також правил виплати щомісячної премії;

- порушення правил виплати грошового забезпечення при звільненні військовослужбовців;

- порушення правил виплати премії та надбавки за наявності Постанови суду про накладення адміністративного стягнення;

- порушення правил виплати одноразової премії згідно з рішенням МОУ;

Найбільш поширеними порушеннями щодо виплати заробітної плати працівникам військових частин $є$ :

- порушення правил встановлення посадових окладів;

- порушення правил виплати надбавки до посадового окладу за роботу, яка передбачає доступ до державної таємниці;

- подвійна виплата матеріальної допомоги;

- оплати праці працівникам за невідпрацьований час;

- оплата праці працівникам за фрактично не виконану роботу.

Основними причинами та умовами, що призвели до виявлених фрінансових порушень стали:

- самоусунення командирів військових частин від контролю за організацією фрінансово-господарської діяльності у військових частинах;

- неналежна організація взаємодії стройових і фрінансових органів щодо своєчасної розробки, передачі до фрінансово-економічної служби витягів із наказів командира частини для виплати грошового забезпечення та заробітної плати, а також фрормальне відношення відповідальних осіб відділення персоналу і стройових до 
підготовки наказів щодо преміювання військовослужбовців та працівників військових частин;

- відсутність у стройових відділеннях належного обліку наданих та використаних щорічних відпусток звільненими військовослужбовцями;

- самоусунення посадових осіб, відповідальних за облік особового складу, у відділеннях персоналу та осіб відділень морально-психологічного забезпечення від виконання покладених обов'язків щодо ведення обліку накладених дисциплінарних стягнень на військовослужбовців.

Також важливою складовою ефективного виконання завдань військовими частинами $€$ ефективна кадрова робота військової частини. Недотримання командуваннями військових частин вимог нормативних документів $з$ питань кадрового менеджменту (тобто відсутність у справах відповідних письмових згод військовослужбовців щодо призначення на нижчі посади) створюють передумови до соціальної напруженості у колективі та виникнення незадоволення в особового складу рішеннями командування з кадрових питань.

Основними причинами неодноразових порушень ведення кількісного обліку є:

- низька професійна підготовка військовослужбовців, призначених (допущених до виконання) посад начальників служб, недостатні знання посадовими особами служб ресурсного забезпечення і підпорядкованих підрозділів положень нормативних документів щодо порядку ведення кількісного обліку та діловодства, відсутність відповідного досвіду за займаною посадою;

- відсутність дієвого контролю за веденням обліку майна служб ресурсного забезпечення з боку заступників (помічників) командирів військових частин та військових частин, які перебували на забезпеченні;

- відсутність контролю з боку керівництва за дотриманням графріку документообігу первинних облікових документів, ведення належного обліку військового майна, своєчасного та повного звітування осіб за використані довіреності на отримання майна, надання матеріалів проведених інвентаризацій, звітів і документів на списання (використання) матеріальних цінностей.

Недотримання начальниками служб ресурсного забезпечення вимог керівних документів щодо порядку організації та ведення обліку призводять до неможливості ведення якісного бухгалтерського обліку військового майна, виникненню численних розбіжностей в обліку, створення передумов до втрати військового майна. Разом з тим, командирами військових частин неналежно забезпечується функціонування внутрішнього контролю, управління ризиками, заходи координації та нагляду за функціонуванням часто не відповідають вимогам нормативних документів. Тому діяльність менеджерів внутрішнього контролю часто має формальний характер. Зокрема, невиконання вимог п. 8.1.1 Порядку № 145 менеджерами внутрішнього контролю, не забезпечується розроблення адміністративних регламентів всіх господарських процесів, що відбуваються в діяльності військової частини. Не завжди проводяться необхідні заходи з моніторингу фактичного виконання визначеним особовим складом заходів контролю та усунення недоліків [4]. У порушення вимог п. 9.1 Порядку № 145 до функціональних обов'язків посадових осіб, що відповідають за здійснення внутрішнього контролю, не вносяться зміни та уточнення посадових інструкцій (функціональних обов'язків) і відповідно не передбачена відповідальність за здійснення відповідних заходів контролю [4].

Як наслідок, у військових частинах та установах інфрормування керівників про стан функціонування внутрішнього контролю та управління ризиками, виконання планів моніторингу внутрішнього контролю, підготовку звітних документів із внутрішнього контролю та вказівок про усунення виявлених недоліків, менеджерами внутрішнього контролю належним чином не здійснюється, що призводить до неповного усунення порушень та виконання пропозицій (рекомендацій), внесених у ході контрольних заходів. Комплекс заходів з внутрішнього контролю, який запроваджений командуванням військових частин, не забезпечує належного дотримання законності, ефективності й економічності використання бюджетних коштів та інших ресурсів, досягнення результатів відповідно до визначених мети, завдань, планів і вимог.

Висновки. Узагальнюючи результати дослідження, зазначимо, що наявність внутрішнього аудиту є невід'ємною складовою ефективного функціонування Міністерства оборони України в умовах швидких змін зовнішнього середовища та ускладнення процесів управління. Використання знань і досвіду внутрішніх аудиторів для виявлення внутрішніх резервів та оцінки можливих ризиків дають змогу підвищити ефективність прийняття управлінських рішень керівництвом. Наведені дані ілюструють досконалу систему внутрішнього контролю та внутрішнього аудиту. Головною запорукою створення системи внутрішнього аудиту українського варіанта - це чітко

встановлені законодавчі норми проведення внутрішнього аудиту в Україні та ЗС України, відсутність двозначності та суперечності, і насамперед, достатня кількість нормативно-правових актів, які регулюватимуть і визначатимуть правильний порядок проведення внутрішнього аудиту та внутрішнього контролю у різних випадках.

Список використаної літератури

1. Бюджетний кодекс України від 08.072010 p №2456-VI. Редакція від 20.09.2015 року.URL: http://zakon2.rada.gov.ua/laws/show/2456-17 (дата звернення: 10.03.2021)

2. Про аудит фінансової звітності та аудиторську діяльність : Закон України від 21.12.2017 р. № 2258-VIII. Дата оновлення 04.03.2020. URL: https://zakon.rada.gov.ua/laws/show/2258-19/print (дата звернення: 10.03.2021).

3. Про організацію діяльності з внутрішнього аудиту в системі Міністерства оборони України : Наказ Міністерства оборони України від 15.12.2020 p. №475.URL:https://www.mil.gov.ua/content/mou_orders/mou 2020/475 nm.pdf (дата звернення: 10.03.2021).

4. Про затвердження Порядку організації в системі Міністерства оборони України внутрішнього контролю та управління ризиками : Наказ Міністерства оборони України від 02.04.2019 р. №145. Дата оновлення 04.03.2020. URL:https://www.mil.gov.ua/content/pdf/vnytr control/n145 020419.pdf (дата звернення: 10.03.2021).

5. Бурлан С. А., Руденко Н. О. Організація і методика аудиту навч. посіб. Миколаїв : вид-во ЧНУ ім. Петра Могили, 2017. 183 с.

6. Основні завдання в рамках реформування Міністерства обоони України та Збройних Сил України. URL: https://www.mil.gov.ua/ diyalnist/vnutrishnij-audit/rezultati-diyalnosti/rezultati-diyalnosti-z-vnutrishnogoauditu-za-2019-rik.html (дата звернення: 10.03.2021)

7. Гончарук Я. А., Рудницький В. С. Аудит. Вид. 2-ге, перероб. та доп. - Львів : Оріяна-Нова, 2004. 292 с.

8. Немченко В. В. Аудит : підручник. [Електронний ресурс]. URL:https://westudents.com.ua/knigi/35-audit-nemchenko-vv.html (дата звернення: 10.03.2021)

9. Аренс Э. А., Лоббек Дж. К. Аудит. 2001. Изд-во "Финансы и статистика. [Електронний ресурc]. URL: https://www.biznesbooks.com/ category/dengi-i-kredit/e-a-arens-dg-k-lobbek-audit (дата звернення: 10.03.2021).

\section{References}

1. Budget Code of Ukraine of July 8, 2010 562456-VI. Edited on September 20, 2015. URL: http://zakon2.rada.gov.ua/laws/show/2456-17

2. On the audit of financial statements and auditing activities: Law of Ukraine of 21.12.2017 № 2258-VIII. Date of update 04.03.2020. URL: https://zakon.rada.gov.ua/laws/show/2258-19/print

3. On the organization of internal audit activities in the system of the Ministry of Defense of Ukraine: Order of the Ministry of Defense of Ukraine dated 15.12.2020 №475.URL: https://www.mil.gov.ua/content/mou orders/ mou_2020/475_nm.pdf

4. On approval of the Procedure for organization of internal control and risk management in the system of the Ministry of Defense of Ukraine: Orde of the Ministry of Defense of Ukraine dated April 2, 2019 №145. URL: https://www.mil.gov.ua/content/pdf/vnytr_control/n145_020419.pdf

5. Burlan, S., Rudenko, N. Organization and methods of audit. Mykolaiv : publishing house Petro Mohyla Black Sea National University. 
6. The main tasks in the framework of reforming the Ministry of Defense of Ukraine and the Armed Forces of Ukraine. URL: https://www.mil.gov.ua/diyalnist/vnutrishnii-audit/rezultati-diyalnosti/rezultatidiyalnosti-z-vnutrishnogo-auditu-za-2019-rik.html (data zvernennia: 10.03.2021).

7. Honcharuk Ya., Rudnytskyi B. (2004). Audit: 2nd edition, revised and supplemented. Lviv: Oriana-Nova.
8. Nemchenko, V. Audit. URL: https://westudents.com.ua/knigi/35 audit-nemchenko-vv.html.

9. Arens, E., Lobbeck, J. Audit. URL: https://www.biznesbooks.com/ category/dengi-i-kredit/e-a-arens-dg-k-lobbek-audit.

Надійшла до редколегії 11.03.21

O. Shramko, Ass. Prof.

Taras Shevchenko National University of Kyiv, Kyiv, Ukraine

alex_shramko@ukr.net

ORCID ID 0000-0002-9080-7750

\section{TYPICAL VIOLATIONS DETECTED DURING THE AUDIT OF MILITARY UNITS OF THE ARMED FORCES OF UKRAINE}

The article considers the general principles of internal audit, the concept, essence, as well as theoretical principles and methodological features of internal audit in the military units of the Armed Forces of Ukraine. Considerable attention is also paid to the purpose of internal audit in general and in the Armed Forces of Ukraine in particular. The definition of audit and internal audit is given in accordance with the norms of current regulations of Ukraine. The process of planning, organization and direct conduct of internal audit, as well as the results of auditors' work is described in detail, the analysis of the regulatory framework for conducting internal audit in budgetary institutions and, in particular, in the Armed Forces of Ukraine. Particular attention is paid to the stages of audit, analysis of typical violations identified in the process of internal audit and internal control. The analysis of the results of the internal audit for 2014-2019 is carried out, the typical violations revealed in the process of internal audit are given, and the violations in 2019 are considered in detail. Low professionalism and negligent performance of duties by officials appointed to the positions of heads of services and relevant officials are common causes of violations of poor records of military property in military services, which have led to losses, risks of illegal expenditures and shortages. military units assigned to support, which in their duties had to work out timely documents on the accounting of material values, spending according to the norms and write-off of military property, keeping books of losses and shortages. Today there is a question of introduction of effective system of the organization of internal audit and adaptation of its technique to activity of budgetary institutions including military units of Armed forces of Ukraine in the conditions of reforming and deepening of integration processes in economy of Ukraine.

Keywords: financial control, internal audit, auditing, auditor, financial statements, military unit, internal financial control. 